Chicago-Kent College of Law

Scholarly Commons @ IIT Chicago-Kent College of Law

All Faculty Scholarship

Faculty Scholarship

January 2008

\title{
Turned on Its Head?: Norms, Freedom, and Acceptable Terms in Internet Contracting
}

Richard Warner

IIT Chicago-Kent College of Law, rwarner@kentlaw.iit.edu

Follow this and additional works at: https://scholarship.kentlaw.iit.edu/fac_schol

Part of the Computer Law Commons, Contracts Commons, Intellectual Property Law Commons, Law and Economics Commons, and the Science and Technology Law Commons

\section{Recommended Citation}

Richard Warner, Turned on Its Head?: Norms, Freedom, and Acceptable Terms in Internet Contracting, 11 Tul. J. Tech. \& Intell. Prop. 1 (2008).

Available at: https://scholarship.kentlaw.iit.edu/fac_schol/691

This Article is brought to you for free and open access by the Faculty Scholarship at Scholarly Commons @ IIT Chicago-Kent College of Law. It has been accepted for inclusion in All Faculty Scholarship by an authorized administrator of Scholarly Commons @ IIT Chicago-Kent College of Law. For more information, please contact jwenger@kentlaw.iit.edu, ebarney@kentlaw.iit.edu. 


\title{
Turned On Its Head?: Norms, Freedom, and Acceptable Terms in Internet Contracting
}

\author{
Richard Warner
}

\begin{abstract}
Is the Internet turning contract law on its head? Many commentators contend it is. Precisely this issue arises in current controversies over end user license agreements (EULAs) and Terms of Use agreements (TOUs, the agreements governing our use of web sites). Commentators complain that, in both cases, the formation process unduly restricts buyers' freedom; and, that sellers and web site owners exploit the process to impose terms that deprive consumers of important intellectual property and privacy rights. The courts ignore the criticisms and routinely enforce EULAs and TOUs. There is truth on both sides of this court/commentator divide. EULAs and TOUs are standard form contracts, and a standard contract formation process can guarantee acceptable terms and enhance freedom; however, in the case of EULAs and TOUs, the process is currently defective in ways that result in unfair terms that reduce freedom. The cornerstone of the analysis is the claim that, when certain ideal conditions are fulfilled, standard form contracting is a freedom-enhancing process yielding acceptable terms. To characterize the ideal formation process, the analysis combines ideas from both the relational theory of contracts and law and economics. Relational theory provides the picture of contracting as a norm-governed activity while an adaptation of a well-known law and economics argument to argue yields the conclusion that, in an ideal formation process, the profitmaximizing strategy for sellers and web site owners is to offer consumers normconsistent contractual terms. I contend that norm-consistent terms are acceptable and freedom-enhancing. The theory applies equally to Internet and non-Internet contracting, and this shows that the Internet is not turning contract law on its head; however, the theory also reveals that Internet contracting poses serious, unmet challenges to contract law. The problem is that EULAs and TOUs contain terms not currently governed by appropriate norms. As a result, the EULA/TOU formation process departs from the ideal formation process in ways that result in unacceptable, freedom-reducing terms. In the case of EULAs, the offending terms involve prohibitions on reverse engineering and transfers of software to third parties. It is likely that relevant norms will evolve relatively soon to govern such terms. In the case of TOUs, the offending terms concern the collection of information by businesses and web sites and implicate privacy concerns. It is unlikely that relevant norms will evolve in relatively soon in this case. How are appropriate norms to be identified or, where necessary, created? The analysis raises but does not answer this question.
\end{abstract}

\section{Table of Contents}

I. Norms and the Assumption of Norm Completeness

A. What Are The Relevant Norms?

1. Norms defined 
2. Contracting as a norm-governed activity

3. Examples

B. Why Does Consistency with Relevant Norms Make Terms Acceptable?

C. Why Are The Provisions In The Contract Consistent With Relevant Norms?

II. Norm-Consistent Terms As Profit-Maximizing
A. The Inconsistency-Detection Assumption
B. Norm-Violation Detectors versus Norm-Inconsistent Sellers
C. Sellers' Inability to Discriminate
D. The Profit-Maximizing Strategy
E. Conclusion

III. Freedom
A. The Argument That Consent Is Not Free
B. The Solution
C. Conclusion

IV. The Lack of Value-Justified Norms in EULAs
A. Two Types of Terms
B. Risk Allocation Terms
C. Normal Course Terms
1. Reverse engineering
2. Transfers to third parties
3. Same problem, other terms
D. Conclusion

V. TOUs

VI. Conclusion 


\title{
Turned On Its Head?: Norms, Freedom, and Acceptable Terms in Internet Contracting
}

\author{
Richard Warner*
}

It is commonplace to contend, as Robert Hillman and Jeffrey Rachlinski do, that "[t]he Internet is turning the process of contracting on its head." ${ }^{\prime \prime}$ Hillman and Rachlinski, suggest that "[c]ontract law, with its quaint origins in cases involving the delivery of cotton by clipper ship or mill shafts by horse-drawn carriage, seems illequipped to respond to contracts made at the speed of light,", and they ask, "Can contract law adapt to this fundamental change in the way people make contracts, or is a new legal order required?"3 They conclude that "existing contract law is up to the challenge."4 My conclusion is more cautious: contract law is mostly-but not entirely — up to the task; critical challenges remain unresolved. I will argue for this claim by considering the current controversy over end user license agreements (EULAs) and Terms of Use agreements (TOUs, the agreements governing our use of web sites). EULAs raise concerns about the interaction between contracts and intellectual property; TOUS, about the interaction between contracts and privacy. I focus first on EULAs.

\footnotetext{
* Professor of Law, Chicago-Kent College of Law; Visiting Foreign Professor, Law Faculty, University of Gdańsk, Poland. I owe thanks for helpful comments and criticism to Graeme Dinwoodie, Steven Harris, and Christopher Leslie. I owe special thanks to Harold Krent and Richard Wright - to the former for typically insightful guidance as to what I am actually trying to say, and to the latter for typically incisive and comments that corrected many false steps.

${ }^{1}$ Robert A. Hillman \& Jeffery J. Rachlinski, Standard-Form Contracting in the Electronic Age, 77 N.Y.U. L. REV. 429, 429 (2002) [hereinafter, Hillman \& Rachlinski]. See also, Mark Lemley, Terms of Use 91 MinN.. L. REV. 459, 459 (2006) [hereinafter, Lemley, Terms of Use] ("Electronic contracting has experienced a sea change in the last decade").

${ }^{2}$ Id. at 430 .

${ }^{3} I d$.

${ }^{4} I d$. at 495 .
} 
Courts and commentators are at odds about EULAs. The commentators decry a contract formation process that the courts take in stride. ${ }^{5}$ The process: a buyer purchases software in a shrinkwrapped box or-as is now more common-by downloading it online; a standard form contract is inside the box (a "shrinkwrap" EULA), or displayed on a splash screen during installation (a "clickwrap" EULA). No negotiation is allowed; by the time the buyer can read the agreement the only options are to return the software, or accept the terms. Where return is not a meaningful option, acquiescence is the only alternative. Mark Lemley has emphasized, the tendency of EULAs to lead to acquiescence. He notes that the return of the software turns out to be sufficiently inconvenient as to be impractical and in any event turns out in practice to be illusory: software vendors and retail stores generally refuse to accept software returned under those conditions. [In addition], the specified conduct that indicates acceptance is the opening of a package and the loading of software the consumer has already paid for--precisely the conduct one would expect the user to engage in if she had been unaware of the shrinkwrap license. ${ }^{6}$

Lemley's points are even more compelling when the software is downloaded online that there is no physical retailer to approach and no physical installation CD to return. In a barrage of criticism that supports the perception that the Internet is "turning contracting on its head," the commentators complain that the formation process unduly restricts buyers' freedom; and, that sellers exploit the formation process to impose excessively seller-favorable terms that deprive buyers of important intellectual property rights. ${ }^{7}$ The

\footnotetext{
${ }^{5}$ See infra n. 6 (academic criticisms) and n. 7 (attitude of the courts).

${ }^{6}$ See Lemley, Terms of Use, supra n. 1 at $.467-68$.

${ }^{7}$ See Robert W. Gromulkiewicz, Getting Serious About User-Friendly Mass Market Licensing for Software, 12 GEO. MASON L. REV. 687, 687 (2004) ("[O]ver a hundred scholarly articles have been written on the subject ... [most of which] criticize EULAs, and argue that courts should not enforce them"). See also Lemley, Terms of Use, supra n. 1 (arguing that free consent is lacking in the case of EULAs and that sellers impose unacceptable terms); Margaret Jane Radin,
} 
courts ignore the criticisms and routinely enforce EULAs (unless they find them objectionable on grounds applicable to contracts generally) ${ }^{8}$ indeed, the leading case, ProCD v. Zeidenberg, ${ }^{9}$ extols the formation process as a cost-effective practice which buyers readily embrace. ${ }^{10}$

There is truth on both sides of this divide. A standard contract formation process can guarantee acceptable terms and enhance freedom; ${ }^{11}$ however, when EULAs are used to sell software, the process is currently defective in ways that result in excessively sellerfavorable terms that reduce freedom. Current contract law has not yet risen to this

Humans, Computers, and Binding Commitment, 75 IND. L.J. 1125 (1999) (arguing that free consent is lacking in the case of EULAs); Robert L. Oakley, Fairness in Electronic Contracting: Minimum Standards for Non-Negotiated Contracts, 42 HouSTON L. REV. 1041, 1065, 1078 (2005) (claiming that "[p]resentation of terms and manifestation of assent are the essence of contract formation," and that "[T] here is no good mechanism for protecting consumers against unfair or oppressive terms in end user license agreements"); compare Hillman \& Rachlinski, supra $\mathrm{n} .1$ (arguing that traditional contract law is largely adequate to address issues arising with EULAs).

${ }^{8}$ See Kevin W. Grierson, Enforceability of "Clickwrap" or "Shrinkwrap" Agreements Common in Computer Software, Hardware, and Internet Transactions, 106 A.L.R.5TH 309 (2003); and Lemley, Terms of Use, supra n. 1 at 460 - 63. The leading case is ProCD v. Zeidenberg, 86 F.3d 1447 (7th Cir.1996), which has been extensively followed. See, e. g., Hill v. Gateway 2000, Inc., 105 F.3d 1147 (7th Cir.1997); Mudd-Lyman Sales \& Serv. Corp. v. United Parcel Service, Inc., 236 F.Supp.2d 907, 911-12 (N.D.Ill.2002); I.Lan Sys., Inc. v. NetScout Serv. Level Corp., 183 F.Supp.2d 328 (D.Mass.2002); Lexmark Int'l, Inc. v. Static Control Components, Inc., 387 F.3d 522, 563 n. 10 (6th Cir.2004). SoftMan Products, 171 F.Supp.2d at 1088, cites Step-Saver v. Wyse Techn., 939 F.2d 91 (2003), and Vault Corp. v. Quaid Software Ltd., 847 F.2d 255 (5th Cir.1988) as holding that shrinkwrap licenses are unenforceable. This is a mistake. In Step-Saver, both parties sent each other forms with different conditions and obligations; the EULA involved was one of the forms exchanged, and the question of its enforceability was a routine battle-of-theforms issue. In Vault, the court did not reach the issue of the validity of EULAs generally because the court found that the buyer knew the terms of the license before purchasing the software. Vault, at 268-70. A case clearly rejecting ProCd is Klocek v. Gateway, Inc., 104 F.Supp.2d 1332 (D.Kan.2000), discussed infra, n.17.

${ }^{9}$ Supra n. 8.

${ }^{10} I d$. at $1451-52$.

${ }^{11}$ See infra Section III. 
challenge as it routinely enforces the offending terms. There is, however, reason to think contract will meet the challenge, and indeed that it will do so relatively soon.

I do not take the same, ultimately sanguine view of a second type of "digital age" contract-Terms of Use Agreements, often referred to as "browsewrap" agreements. Terms of Use Agreements (TOUs) govern the rapidly increasing variety of social, political, and commercial purposes for which we use web sites. Like EULAs, TOUs are no-negotiation, standard form agreements; unlike EULAs, one may read them at any time since they are routinely accessible via hyperlinks at the bottom of home pages. Web site visitors are, however, neither asked nor required to assent to the terms by clicking on an "I agree" button or by performing any other similar affirmative act of assent, ${ }^{12}$ thus, visitors may, and typically do, just "browse" on by without reading, or even opening, the agreement. ${ }^{13}$ The result is that, as with EULAs, passive acquiescence is the rule. Web site owners may—and do—exploit this fact to impose terms which unacceptably compromise web site visitor's privacy. ${ }^{14}$ Unfortunately, the prospects for rectifying this situation appear considerably dimmer than they do in the case of EULAs. TOUs pose the most significant challenge to current contract law.

The cornerstone of my analysis is the claim that when certain ideal conditions are fulfilled, standard form contracting is a freedom-enhancing process yielding acceptable terms. To characterize the ideal formation process, I combine themes and ideas from both the relational theory of contracts and law and economics. Relational theory provides

\footnotetext{
${ }^{12}$ See, e. g. Specht v. Netscape, 306 F.3d 17 (S.D. N.Y. 2001) (describing the TOU formation process).

${ }^{13}$ See infra n. 16.

${ }^{14}$ See infra Section IV.
} 
the picture of contracting as a norm-governed activity. Section I defines the relevant concept of a norm and also defines the key notion of a value-justified norm. Section I also introduces the first assumption characterizing the ideal formation process- the assumption (roughly) that contractual terms are consistent with relevant, value-justified norms. Section II adapts a well-known law and economics argument to complete the characterization of the ideal formation process and argue that, in such a process, the profit-maximizing strategy for sellers is to offer buyers norm-consistent contractual terms.

Sections I and II comprise my main theoretical contribution: a novel, norm-based theory of standard form contracting. The theory applies equally to Internet and nonInternet contracting, and this shows that the Internet is not turning contract law on its head; however, the theory also reveals that Internet contracting poses serious, unmet challenges to contract law. The consideration of EULAs and TOUs in Sections III and IV analyze these challenges. Section III argues that the criticisms of the commentators show that the use of EULAs fails to approximate the ideal formation process. The problem is that they contain certain key terms concerning intellectual property rights where those terms are not governed by value-justified norms. It follows that the terms are unacceptable and reduce freedom; consequently, legal intervention is (most likely) required. However, once the lack of value-justified norms is remedied, the use of EULAs will yield acceptable terms and enhance freedom (assuming that there are no other reasons their use fails to sufficiently closely approximate the ideal formation process). Section IV argues for an essentially similar result in the case of TOUs: they contain terms allowing the site to collect information about visitors, where those terms are not 
governed by value-justified norms. There is one critical difference. While there is reason to think that the defects in EULAs can be relatively easily remedied, there is less reason to be optimistic about remedying similar defects in TOUs. TOUs pose the most difficult challenge to current contract law.

\section{Norms and the Assumption of Norm Completeness}

When the contract formation process meets certain ideal conditions, standard form contracting is a freedom-enhancing process yielding acceptable terms. The same point holds in actual practice to the extent that practice approximates the ideal. I will not, however, make any claim about the extent to which practice approximates the ideal. My claim is normative: we should try to ensure that practice approximates the ideal. We should promote freedom because free self-direction is the hallmark of the thoughtful, democratic citizen who guides his or her actions by principles freely adopted as the result of critical reflection. We value such self-direction for its own sake. ${ }^{15}$ Failures to realize the ideal formation process can provide grounds for legal invention designed to bring practice closer to the ideal; in the case of EULAs and TOUs, there are failures justifying such intervention. There are three conditions which characterize the ideal formation process. This section characterizes the first; the next section, the remaining two.

I begin by describing the purchase of a typical consumer good. The contract is presented after payment and delivery, and the transaction concludes—as is typical—with

\footnotetext{
${ }^{15}$ See Joseph RAZ, THE Morality OF FreEdom (1986); see also GERALD DWORKIN, ThE THEORY AND PRACTICE OF AUTONOMY (1988).
} 
the buyer not reading the contract. ${ }^{16}$ The example: when typical-buyer Carol discovers that her water heater no longer works, she phones Sears, orders a new one, and pays with a credit card. After the workers finish the installation, they hand her an envelope as they leave. The contract from the manufacturer of the water heater is inside. ${ }^{17}$ Carol understands that the contract imposes legally binding obligations, and it is important to her that those obligations should be acceptable (she cares about the warranties, for example ${ }^{18}$ ); however, like most consumers, she does not read the contract; she just files it

\footnotetext{
${ }^{16}$ Many have observed that buyers do not as a rule read standard form contracts. See Robert A. Hillman, On-line Consumer Standard-Form Contracting Practices: A Survey and Discussion of Legal Implications, in JANE WINN (ED.) CONSUMER PROTECTION IN THE AGE OF THE 'INFORMATION ECONOMY' (2006) [hereinafter, Hillman, Survey](reporting survey results supporting the claim that online buyers do not read contracts); Melvin Aron Eisenberg, The Limits of Cognition and the Limits of Contract, 47 STAN. L. REV. 211, 240-41 (1995) ("[C]onsumers who are faced with the dense text of form contracts characteristically respond by refusing to read"); Michael I. Meyerson, The Reunification of Contract Law: The Objective Theory of Consumer Form Contracts, 47 U. MIAMI L. REV. 1263, 1269-70, 1275 (1993) ("It is no secret that consumers neither read nor understand standard form contracts"); Melvin Aron Eisenberg, Text Anxiety, 59 S. CAL. L. REV. 305, 309 (1986) (dense form contract language discourages consumers from reading terms).

${ }^{17}$ In a retail transaction, the buyer typically enters two contracts-one with the manufacturer (containing warranties among other terms), and one with the retailer (end-seller). In the latter case, the retailer is the offeree. See Klocek, supra n. 8, at 1341. In the former, the manufacturer is the offeror. See ProCD, supra n. 8, at 1452. The Klocek court overlooks this distinction when it objects to the ProCD decision on the ground that the software manufacturer, ProCD, is the offeree, not the offeror. Klocek, supra n. 8, at 1341.

${ }^{18}$ William R. Darden \& C. P. Rao, A Linear Covariate Model of Warranty Attitudes and Behaviors, 16 JOURNAL OF MARKETING RESEARCH 466, 475 (1979) [hereinafter, Darden \& Rao] concludes that "most consumers are indifferent or they are supporters of warranties in their present form." A "supporter" finds the warranty a factor in the purchase decision; an "indifferent" consumer does not. Darden and Rao do not, however, distinguish between, whether a consumer cares that the terms be acceptable, and whether the consumer expects the manufacturer to comply in a meaningful fashion with those terms. Darden and Rao emphasize consumer dissatisfaction with manufacturers' responses to warranty claims; however, more recent studies find less dissatisfaction. See Jean Braucher, An Informal Resolution Model of Consumer Product Warranty Law, 1985 WIS. L. REV. 1405, 1447 - 57 (presenting evidence that businesses generally respond to product complaints in ways consumers find satisfactory). See also YeonKoo Che, Customer Return Policies for Experience Goods, 44 J. INDUS. ECON. 17 (1996); and, Claes Fornell \& Biger Wernefelt, A Model for Consumer Complaint Management, 7 MARKET SCI. 287 (1998)
} 
with the other unread contracts for other appliances she has purchased. ${ }^{19}$ She does not read the contract because she thinks she does not need to. What she cares about is that the terms should be acceptable, and she assumes they are. She assumes this because she assumes that they are consistent with relevant norms. This raises three questions. What are the relevant norms? Why are provisions consistent with those norms acceptable? Why is it true that the provisions in the contract are consistent with the relevant norms? Answering these questions is the first step toward characterization of the ideal formation process.

\section{A. What Are The Relevant Norms?}

I answer the question by offering examples. Two preliminaries are necessary: a definition of norms, and the observation that contracting is, in the sense defined, a normgoverned activity.

\section{Norms defined}

A norm is a sanction-supported behavioral regularity in a group of people, where the regularity exists in part because each group member thinks that, other things being equal, each group member ought to act in accord with that regularity. ${ }^{20}$ The "ought" may be purely prudential, justified by a fear of legal and non-legal sanctions; or, it may be

\footnotetext{
${ }^{19}$ See supra n. 16.

${ }^{20}$ See Michael Hector and Karl-Dieter Opp, What Have We Learned About the Emergence of Social Norms?, in MichaEl HeCTOR \& KARL-DieTER OPP (EDS.), SOCIAL NORMS 394, 403 (2001). There are various definitions of norms, and it would be a mistake to wonder which one is the "correct" definition. There are just different concepts serving different theoretical purposes. The text defines the concept of a norm that serves my purposes here.
} 
justified in light of the values the person accepts. As an example of a norm, imagine you are about to enter an elevator in which several others are already present. Where do you stand? The norm is (roughly) that you should, other things being equal, maximize the distance between you and the person nearest you.

My critique of EULAs and TOUs rests on a distinction between two types of norms: those that are, and those that are not, value-justified. I contend that certain significant terms in EULAs and TOUs are not governed by value-justified norms and hence that legal intervention is required. What, then, is a value-justified norm? To answer, consider first that we typically conform to norms without much thought; when you step into an elevator, for example, you just unreflectively stand in the appropriate spot. You think you ought to stand there, but you do not worry or wonder about the justification for that "ought." The crucial point to emphasize is that you could justify it; you could, that is, if you reflected on the norm under appropriate ideal conditions (including having sufficient time, information, lack of bias, and so on). You could justify the balance the norm strikes between the value you place on not feeling crowded, and the value you place on being able to use the elevator when it arrives. ${ }^{21}$ In general, with regard to many (but, importantly, not all) norms, we would, given ideal conditions for reflection, regard conformity to the norm as justified in light of our values. ${ }^{22}$ Call such norms value-justified. Not all norms are value-justified. As an example of the latter sort of norm, imagine a norm which requires selecting men instead of women for police

\footnotetext{
${ }^{21}$ Justification comes in degrees, of course: our values may more or less justify a norm. I suppress this complication for the sake of simplicity.

${ }^{22}$ The appeal to reasoning under ideal conditions to justify normative conclusions begins (at least) with Aristotle. See Aristotle, NicOMACHEAn ETHICS. For a modern exposition and defense of this approach, see STEPHEN DARWALL, IMPARTIAL REASON (1983).
} 
officers. Assume that, even though most unreflectively abide by the norm, they would not regard the norm as justified if they were to reflect on it adequately in an unbiased way.

\section{Contracting a norm-governed activity}

Contracting occurs against a background of norms, where the norms are valuejustified. $^{23}$ Two distinct theoretical approaches to contract law--relational theory, and behavioral law and economics—-have converged on this conclusion (albeit without the emphasis on value-justified norms), and I rely on their arguments. ${ }^{24}$ I do, however, need to be explicit about what I assume in regard to contract norms.

I assume that for any possible contractual provision, there is at least one relevant, value-justified norm with which the provision is consistent or inconsistent (where a "relevant" norm is one the parties regard as relevant to deciding whether they should

\footnotetext{
${ }^{23}$ The norms vary from group to group. For example, Darden and Rao suggest that, in the case of warranties, higher income consumers may prefer higher prices and longer warranties while lower income consumers may prefer lower prices and shorter warranties. Darden \& Rao, supra n. 18, at 475. For simplicity I take the relevant group to be all United States consumers.

${ }^{24}$ Relational contract theory began with an empirical study by Stewart Macaulay. Stewart Macaulay, Non-Contractual Relations in Business: A Preliminary Study, 28 AMERICAN SOCIOLOGICAL REVIEW 55 (1963). Ian McNeil developed the idea of a relational contract in Contracts: Adjustment of Long-Term Economic Relations Under Classical, Neoclassical and Relational Contract Law, 72 Nw. L. REV. 854 (1978). For more recent work emphasizing the role of norms, see, e. g., Lisa Bernstein, Private Commercial Law in the Cotton Industry: Creating Cooperation Through Rules, Norms, and Institutions, 99 MICH. L. REV. 1724 (2001); Stewart Macaulay, Relational Contracts Floating on a Sea of Custom? Thoughts About the Ideas of Ian MacNeil and Lisa Bernstein, 94 NW. U. L. REV. 775 (2000); Patrick J. Kaufmann \& Louis W. Stern, Relational Exchange Norms, Perceptions of Unfairness, and Retained Hostility in Commercial Litigation, 32 JOURNAL OF CONFLICT RESOLUTION 534, 535 (1988) (noting that norms "exist in all exchange behavior, from very discrete transactions to highly relational exchange"). For the law and economics perspective on norms, see e. g. ERIC POSNER, LAW AND Social Norms (2000), and James S. Coleman, Norms As Social Capital, in G. Radnitsky \& P. Bernholz (eds.) ECONOMIC IMPERIALISM: THE ECONOMIC APPROACH APPLIED OUTSIDE THE FIELD OF ECONOMICS (1987).
} 
agree to and be bound by a term). Call this the norm completeness assumption. Norm completeness is the first of the three assumptions which characterize the ideal formation process. Norm completeness is an ideal that actual practice only approximates. In practice, it may be unclear exactly what the relevant norms are (especially in the case of norms which resist complete articulation), or relevant norms may not even exist. In addition, for simplicity, I assume that consistency with norms is an all-or-nothing matter: a provision is either entirely consistent or entirely inconsistent. In practice, consistency is often a matter of degree. Finally, I assume, in regard to value-justification, that our values show either that we ought to act in accord with a given norm, or that we ought not. In practice, there may be open questions where our values do not show that we ought to act in accord with the norm but also do not show that we ought not.

The idealizations built into the norm completeness assumption are justified because the role of the assumption is to characterize the ideal formation process. It is, however, worth noting that it is plausible that norm completeness is approximately true in actual practice. The point is to forestall the objection that the ideal formation process is so unattainable in reality as to be irrelevant as a normative guide to action. It is plausible that practice more or less approximates norm completeness because manufacturers have used standard form contracts for over a century, and it would be quite implausible to suggest that, over the years, relevant contractual norms have failed to evolve for at least some types of products and services. ${ }^{25}$

\footnotetext{
${ }^{25}$ Standard form contracting began with the development of mass production in the late nineteenth century. See Friedrich Kessler, Contracts of Adhesion-Some Thoughts About Freedom of Contract, 43 COLUM. L. REV. 629, 631 (1943). Standardized warranties appeared around the same time. See George L. Priest, A Theory of the Consumer Product Warranty, 90 YALE L.J. 1297, 1299 (1981). The article presents empirical results in support of the claim that the warranty terms in standard form contracts are best explained as an optimal allocation of the
} 


\section{Examples}

I conclude with three examples of value-justified norms relevant to contracts.

The first is, "Do not deceive another about a material element of a contract."

Contracting parties (some at least) conform to this regularity in part because they think they ought to. Parties may conform to the non-deceitfulness norm unreflectively (in the way we unreflectively enter elevators and assume our proper place), but it is certainly plausible that the norm is value-justified. That is, it is plausible that everyone would, after sufficient, adequately informed, and unbiased reflection, regard conformity to the norm as justified. The "do not deceive" norm is one of many norms governing the behavior of contracting parties. Such norms answer the question, "What should so-andso type of contracting party do in such-and-such type of situation?" It is helpful to distinguish such norms from those which answer the question, "Should so-and-so type of contract contain such-and-such type of term?"26 The next example illustrates such a norm.

Consider the provision, typically found in contracts for the sale of refrigerators, which makes the manufacturer liable for defects in the motor, shelves, and doors and the buyer liable for damage to the same. This allocation of risk implements this norm: other things being equal, the party who can most cost-effectively prevent a loss - the best loss-

risk of product malfunctions between the manufacturer and the buyer. To the extent such a risk allocation has become a sanction-supported regularity to which buyers and sellers think they ought to conform, the risk allocation is a norm.

${ }^{26}$ For a study of norms governing contractual terms, see PRANAB BARDHAN, LAND, LABOR, AND RURAL POVERTY: ESSAYS IN DEVELOPMENT ECONOMICS (1984) (invoking norms to explain the very high degree of uniformity in terms in land contracts). 
avoider--should bear that loss. ${ }^{27}$ This is the manufacturer in regard to defects because it has more expertise and benefits from economies of scale; the buyer, on the other hand, is the best loss-avoider in regard to damage to the motor, doors, and shelves since the buyer may avoid damage simply by using those items in a reasonable way. ${ }^{28}$ Like the nondeceitfulness norm, it is plausible that this norm is value-justified.

It is instructive to compare the "best loss-avoider" norm to the third, and final, example: namely, a seller (within broad limits) may disclaim consequential damages. It may seem at first sight that this cannot be a norm. A norm is a sanction-supported regularity where the regularity exists in part because people think they ought to conform to it. "Sellers may disclaim consequential damages" does express a sanction-supported regularity; sellers regularly disclaim consequential damages, and courts regularly enforce the disclaimers. But how can it be true that buyers think they ought to conform to the regularity? The vast majority of buyers do not even know what consequential damages are, let alone realize that sellers are allowed to disclaim them; so, how can it be true that buyers think they ought to accept and abide by the disclaimers? The answer is that, as empirical studies confirm, people think that they ought to abide by the law (other things being equal). ${ }^{29}$ Hence, since the disclaimer of consequential damages is a legally

${ }^{27}$ In this case, the "other things being equal" rider is particularly important. Best loss-avoider concerns are just one of the many considerations that guide our judgment about who should bear a loss. We may, for example, think that someone who commits an intentional tort should bear the losses he or she causes even if the victim is the best loss-avoider. See generally Richard Wright, The Principles of Product Liability, in Symposium, Products Liability Litigation Trends on the 10th Anniversary of the Third Restatement, 26 REVIEW OF LITIGATION 1067 (2007)

${ }^{28}$ Alan Schwartz \& Louis L. Wilde, Imperfect Information in Markets for Contract Terms: The Examples of Warranties and Security Interests, 69 VA. L. REV. 1387, 1398 (1983) [hereinafter, Schwartz \& Wilde, Imperfect Information].

${ }^{29}$ Tom Tyler, Why PeOPle Obey The LAW 64 (1990) (arguing, based on empirical studies, that people think they ought to obey the law). See also MARK KELMAN, A Guide To Critical 
enforceable provision, it follows that buyers think that they ought to abide by it. In such cases, legal enforceability results in a sanction-supported regularity to which people think they ought to conform. Call such norms, legally-generated norms.

In the case of such norms, it is particularly important to invoke the distinction between norms that are value-justified and those that are not. Grant, for the sake of argument, that allowing sellers to disclaim consequential damages is value-justified; grant, that is, that after sufficient, adequately informed, and unbiased reflection, we would regard the norm as justified. Then, the legally implemented norm reflects our implicit evaluative judgment; on the other hand, where courts or legislatures ignore or misinterpret the relevant community values, they may very well create a legallyimplemented norm which is not value-justified. Such a norm would not reflect our implicit evaluative judgment. This is what has happened in the case of EULAs and TOUs.

B. Why Does Consistency with Relevant Norms Make Terms Acceptable?

Why does Carol find terms consistent with relevant, value-justified norms acceptable? In the refrigerator example, for instance, the relevant norm dictates that the manufacturer should be liable for defects and the buyer for damage. Wouldn't Carol prefer that the manufacturer bear liability for damage? To answer, consider first that Carol herself adheres to the relevant norms. If she were to insist on terms more favorable to her than the norms allow, she would be violating her own standards, demanding what she thinks she ought not to demand. Some may object that we can still nonetheless imagine Carol insisting on more favorable terms. This does not, however, show that Legal StUdies 263 - 68 (1987), and David Kairys, Introduction to THE POLITICS OF LAW 7 (David Kairys, ed., 1990). 
Carol does not find acceptable terms consistent with value-justified norms; it merely shows that Carol, like all of us, can be tempted by what she nonetheless thinks she should not have. I conclude that terms consistent with value-justified norms are acceptable in the sense that in agreeing to such terms we agree to act in ways we think we ought to act.

It bears emphasis that the conclusion would not follow without the assumption that the norms are value-justified. If a norm fails to be value-justified, then our values lead to the conclusion that we ought not to act in accord with a given norm. A contractual term that requires you to act in accord with such a norm requires you to do what you think you ought not. Such a term is not acceptable in the sense intended here: acceptable terms are terms governed by norms justified in light of our values.

\section{Why Are The Provisions In The Contract Consistent With Relevant Norms? \\ Carol assumes that the terms in the Sears' contract are consistent with relevant}

norms. She is typical; at least where they are dealing with an established reputable seller, consumers expect more or less norm-consistent terms. ${ }^{30}$ But why is the assumption of norm-consistent terms true? Many commentators find it obvious that sellers will exploit

${ }^{30}$ As Hillman and Rachlinski note,

Businesses' concern with their reputations provides a . . . barrier to the exploitation of consumers. Businesses must worry that if they consistently include terms that exploit that consumer and enforce such terms, the will develop an unsavory reputation ... Consumers can thus protect themselves . . . by selecting only those [businesses] with a good reputations.

Hillman \& Rachlinski, supra n. 1, at 442 - 43. See also Daniel T. Ostas, Postmodern Economic Analysis of Law: Extending the Pragmatic Visions of Richard A. Posner, 36 AM. Bus. L.J. 193, 229 (1998) (arguing that consumers do not read boilerplate because they trust terms are customary to industry and reasonable "in light of community notions of fairness"); Todd D. Rakoff, Contracts of Adhesion, An Essay in Reconstruction, 96 HARV. L. REV. 1173, 1230 ("An analysis recognizing the existence of contracts of adhesion in price-competitive markets admits that the costs saved by shifting risk to the customers via form terms may well be returned to the customer by means of lower prices or more advantageous terms concerning the few items that are generally bargained or shopped for"). 
the fact that most buyers do not read standard form contracts to impose excessively seller-favorable terms. ${ }^{31}$ Why think otherwise? Because offering norm-consistent terms is the best strategy for maximizing profits; hence, rational profit-motive driven sellers do so. ${ }^{32}$ The argument merits its own section.

\section{Norm-Consistent Terms As Profit-Maximizing}

I begin with a summary of the argument: (1) whenever a contract contains a norm-inconsistent term, at least some buyers will notice the inconsistency. (2) Buyers who detect a norm-violation will not, other things being equal, buy from sellers offering norm-inconsistent terms; (3) sellers are unable to discriminate between buyers who will, and those who will not detect a norm-inconsistency; therefore, (4) where the market is

${ }^{31}$ See Jason Scott Johnson, The Return of the Bargain: An Economic Theory of How StandardForm Contracts Enable Cooperative Negotiation Between Businesses and Consumers, $104 \mathrm{MICH}$. L. REV. 857, 861 (2006) ("By the 1970's, both courts and commentators had reached a virtual consensus [that] ... consumer product manufacturers had unbridled discretion to draft standardform terms such as warranties simply to minimize their costs"). For relatively recent examples of the claim that sellers will exploit consumers, see Melvin Aron Eisenberg, The Limits of Cognition and the Limits of Contract, 47 STAN. L. REV. 211, 242- 43 (1995); Michael I. Meyerson, The Reunification of Contract Law: The Objective Theory of Consumer Form Contracts, 47 U. MIAMI L. REV. 1263, 1269-73, 1275 (1993); David Slawson, The New Meaning of Contract: The Transformation of Contracts Law by Standard Forms, 46 U. PITT. L. REV. 21, 44 (1984).

32 The argument is adapted from the influential article by Schwartz \& Louis L. Wilde, Intervening in Markets on the Basis of Imperfect Information: A Legal and Economic Analysis, 127 U. PA. L. REV. 630 (1979) [hereinafter, Schwartz \& Wilde, Intervening]. Jason Johnson emphasizes Schwartz and Wilde's role in countering the 1970's hostility toward standard form contracting. Johnson, supra n. 30, at $862-63$. Johnson offers the following summary of the Schwartz and Wilde argument:

Schwartz and Wilde demonstrated in a general theoretical setting how even a quite small proportion of smart consumers who actually read and shopped for standard-form contract clauses could put enough competitive pressure on firms so that they would adopt efficient standard-form terms (terms whose cost to the firm was less than the value that consumers placed on them.

Id. There are two key differences between the Schwartz and Wilde argument and the one I offer. First, I assume contracting is a norm-governed activity while Swartz and Wilde make no mention of norms. Second, my argument proposes a normative ideal while Schwartz and Wilde claim to model actual practice. 
sufficiently competitive with respect to terms, the profit-maximizing strategy is to offer all buyers norm-consistent terms.

\section{A. The Inconsistency-Detection Assumption}

Most buyers do not read standard form contracts, so, why think that, whenever a contract contains a norm-inconsistent term, at least some buyers will notice the inconsistency? I will not argue for this claim; I will simply assume it is true. This-the inconsistency-detection assumption-is the second of the three idealizations which characterize the ideal formation process, and the justification for the assumption is that its role is limited to the characterization of that ideal. However, as with the norm completeness assumption, it is worth noting that practice does reasonably closely approximate the detection assumption.

To this end, consider that the inconsistency-detection assumption is extremely weak; it assumes only that some buyers detect norm-violations; it makes no claim about how many. It is the third assumption—-the assumption of a sufficiently term-competitive market— that includes such a claim. ${ }^{33}$ It is certainly plausible that a norm-inconsistent term will not escape the notice of every buyer. To begin with, some buyers do read

33 Compare the "informed minority" assumption that plays a key role in the Schwartz and Wilde argument. They assume: (1) an informed minority of buyers detect terms in standard form contracts that conflict with their preferences; (2) such buyers will not buy from sellers offering such contracts; and (3) the number of non-buying informed buyers is sufficiently great that the lost profit is greater than any gain the seller realizes from the offending terms. Schwartz \& Wilde, Intervening, supra n. 32, at 635 - 639. See also Schwartz \& Wilde, Imperfect Information, supra n. 28, at 1417 - 1418. Part (3) of the "informed minority" assumption has proven controversial. See R. Ted Cruz \& Jeffery J. Hinck, Not My Brother's Keeper: The Inability of an Informed Minority to Correct for Imperfect Information, 47 HASTINGS LAW JOURNAL 635 (1996) [hereinafter, Cruz \& Hinck] (arguing that (3) is false). I assume a version of (3) later, but not as an empirical claim; I assume it as part of the characterization of the ideal formation process. See infra n. 41 and accompanying text. 
contracts. ${ }^{34}$ Professional buyers purchasing for businesses and organizations read when their purchasing decision depends not just on price and quality but also on the contractual terms. ${ }^{35}$ This is especially likely to be true where the buyer is dealing with a seller of unknown or uncertain reputation. Non-professional purchasers may read for the same reason; or, because they think that it is a mistake to enter a contract without reading it; or, because they value knowing all relevant aspects of a commercial transaction; or for some other reason. It is, however, not necessary to read a contract to be aware of norminconsistent terms. Sellers can ensure that non-readers possess the information about contractual terms which they would have acquired had they read the contract. If Hertz, for example, offers rental cars on contractual terms which violate relevant norms while Avis does not, Avis' advertising may very well call this to the attention of potential Hertz customers. ${ }^{36}$ Awareness of norm-inconsistent terms can also come from publications like Consumer Reports, consumer watch-dog groups, and negative publicity from consumer complaints and litigation. ${ }^{37}$

B. Norm-Violation Detectors versus Norm-Inconsistent Sellers

\footnotetext{
${ }^{34}$ See Hillman, Survey supra n. 16 (noting that some online buyers do read contracts).

${ }^{35}$ Frank Easterbrook, Contract and Copyright, 42 Houston L. REV. 953, 970 (2005).

${ }^{36} I d$. at 968 .

${ }^{37}$ See Robert A. Hillman, Online Boilerplate: Would Mandatory Website Disclosure of EStandard Terms Backfire, 104 MiCH. L. REV. 837, 853 (2006) (hereinafter, Hillman, Boilerplate] (discussing the role of watchdog groups).
} 
When buyers detect a norm-inconsistent provision in a seller's contract, they will not-other things being equal--buy from that seller. ${ }^{38}$ To see why, recall that a norm specifies a regularity to which group members believe they ought to conform. Normviolation detectors will, therefore, perceive a norm-inconsistent seller as not treating them as they ought to be treated. Other things being equal, buyers will purchase from sellers they perceive as treating them as they ought to be treated, not from those whom they perceive as not doing so-assuming norm-consistent sellers exist. ${ }^{39}$ The third assumption, introduced shortly, ensures that such sellers exist.

\section{Sellers' Inability to Discriminate}

How will sellers respond to the existence of norm-violation detectors who will, other things being equal, not buy from sellers offering norm-inconsistent contractual terms? If sellers could reliably discriminate between buyers who will, and those who will not, detect a norm-inconsistency, it would be possible for sellers to offer norm-consistent terms to the inconsistency-detectors and more seller-favorable, norm-inconsistent terms to the rest. In mass market contexts, however, sellers cannot reliably discriminate. ${ }^{40}$

\footnotetext{
${ }^{38}$ This will seem implausible if one thinks of trivial norms. Why, for example, would buyers be deterred from buying if the contract was printed in Verdana even though the norm was to use Times New Roman? The claim concerns norms which resolve substantive questions about how contracting parties ought to behave.

${ }^{39}$ See J. R. Avrill, Studies on Anger and Aggression, 38 AMERICAN PSYCHOLOGIST 1145 (1983) (noting that violation of norms in an exchange provokes anger and may lead to the termination of the exchange). The argument in the text provides a theoretical rational for Avrill's results.

40 See Schwartz \& Wilde, Intervening, supra n. 32, at 663 - 67 (arguing that sellers cannot discriminate between relevant types of buyers in mass market transactions); Cruz \& Hinck, supra n. 33 , at $672-675$, argue that sellers may be able to discriminate between different types of buyers; however, only one of their arguments (Id. at 673) explicitly addresses the ability of sellers to differentiate between buyers based on their attitudes toward contractual terms, and that argument does not address the ability of sellers to tell whether or not a buyer will detect a norm-
} 
When you walk into a retail store or order an item over the phone or online, nothing reliably signals the seller whether or not you will detect norm-inconsistent terms-unless you try to negotiate. If you detect a norm-inconsistent term and object to it on that basis, you reveal yourself as a norm-violation detector. I am, however, focusing on those cases where negotiation is either not allowed, or not desired by the buyer-as is typical in the case of purchasing water heaters, hair dryers, personal computers, and the like.

\section{The Profit-Maximizing Strategy}

The final claim is that, when sellers cannot discriminate between those who do, and those who do not, detect norm-inconsistencies, then, in a sufficiently termcompetitive market, the profit-maximizing strategy is to offer all buyers norm-consistent terms; hence, rational, profit-motive driven sellers will do so. The argument begins by stating the conditions for a sufficiently term-competitive market. There are two conditions; they comprise the third assumption characterizing the ideal formation process--the assumption of a sufficiently term-competitive market. First: multiple sellers offer more or less equivalent products at more or less the same price; buyers can just as easily buy from one seller as another, and sellers do not collude to ensure that they all offer the same contractual terms. ${ }^{41}$ Second: there are enough norm-violation-detecting

inconsistent contractual term; on the contrary, the argument assumes a sales-person explicitly proposes a contractual term, and hence assumes a context in which detection of norminconsistency would be likely.

${ }^{41}$ The first condition is adapted from, but weaker than, the requirement of a price competitive market. A market is perfectly price competitive when there is a large number of independently acting (non-colluding), sufficiently informed, small producers and consumers, no one of whom can unilaterally significantly affect price or supply; sell homogenous goods and services in a market in which competitors may costlessly enter and leave. See, e. g., JEFFERY L. HARRISON, LAW AND ECONOMICS 261 (2007). 
buyers that a seller's gain from offering a norm-inconsistent term is smaller than the loss which results if norm-violation-detectors are able to buy from a norm-consistent seller. ${ }^{42}$ The first condition a seller offering a norm-inconsistent term will (other things being equal) lose the business of every norm-violation-detecting buyer-provided that at least one seller offers entirely norm-consistent terms. This follows from the fact that, other things being equal, buyers who detect a norm-violation in a seller's contract will not buy from that seller. The "other things being equal" rider merely concerns trivial exceptions which do not matter here (e. g., the buyer purchases from a norm-inconsistent seller because the seller is a relative). The second condition ensures that there will be normconsistent sellers. Thus, when both conditions hold, the profit-maximizing strategy is to offer all buyers norm-consistent terms, and hence, rational, profit-motive driven sellers will do so.

It is instructive to compare the assumption of a sufficiently term-competitive market with the norm completeness and inconsistency-detection assumptions. In the latter cases, it is plausible that practice reasonably closely approximates the ideal. Is the same true of the assumption of a sufficiently term-competitive market? Opinion is divided; some take the claim for granted while others raise doubts. ${ }^{43}$ Neither side in the

\footnotetext{
${ }^{42}$ Compare Swartz \& Wilde, Intervening, supra n. 32, at 661 - 663. They propose that there is lack of sufficient term-competition (in their terminology, a "monopolistic" market with respect to terms) if "(1) the market is not price competitive; and (2) the term at issue appears in arcane legal language and fine or otherwise inconspicuous print." Id. at 662 . The point of (2) is to identify those cases in which there is a high cost to consumers of searching for and understanding relevant contractual terms; the idea is that in such cases "too few searchers may exist to generate a nonmonopolistic term structure." Id.

${ }^{43}$ Cruz \& Hinck supra n. 33 summarize the debate and argue against the assumption of a termcompetitive market. Cruz and Hinck's model does not take into account the fact that a court is highly likely to refuse to enforce clearly norm-inconsistent terms on grounds of unconscionability in a standard form contract between a merchant and a consumer. This means the gain from a
} 
debate, however, denies the normative importance of the ideal of a term-competitive market as a guide in determining when legal regulation may be appropriate in practice. Since I am only proposing term-competitiveness as a normative goal, I will put to one side the question of the extent to which term-competitive markets exist in practice.

\section{E. Conclusion}

We have reached the conclusion that, in an ideal formation process, rational, profit-motive driven sellers will offer all buyers norm-consistent terms. Two further conclusions follow: the terms are acceptable; and, they enhance freedom. The norm completeness assumption ensures acceptability. The norm-completeness is the assumption that for any possible contractual provision, there is at least one relevant, value-justified norm with which the provision is consistent or inconsistent. In the ideal formation process, all terms will be norm-consistent. A term consistent with all relevant value-justified norms is acceptable - in the sense that buyers regard (or would on reflection regard) the terms as ones they ought to accept and to which they ought to conform. The next section argues that, given an ideal formation process, the use of standard form contracts promotes freedom.

\section{Freedom}

In a no-negotiation, standard form contract, buyers are constrained to accept the terms, and constrained choices are the example par excellence of unfree choices. For

norm-inconsistent term would be short-lived and hence less likely than Cruz and Hinck suggest to outweigh associated losses. For a recent assertion that "[c]ompetition for market share in the eenvironment may ... deter businesses from drafting onerous terms or even motivate them to write terms favorable to consumers," see Hillman, Boilerplate, supra n. 37, at 853. 
example, when the thief, with a gun to your head, demands, "Your money or your life!", the thief violates your freedom by compelling your choice. You have only one meaningful option: hand over your money. Standard form contracting hardly rises to the level of gun-to-the-head compulsion; nonetheless, where refusing to enter the contract is not a meaningful option, no-negotiation contracting does share with the gun-to-the-head example the feature that your options are reduced to one. So, how can buyers freely assent to the terms of a standard form contract? There are seemingly compelling considerations that the answer is that they cannot.

\section{A. The Argument That Consent Is Not Free}

Margaret Radin argues forcefully that our consent to standard form contracts is not free. She contends that free "[c]onsent requires a knowing understanding of what one is doing in a context in which it is actually possible for one to do otherwise, and an affirmative action in doing something, rather than a merely passive acquiescence in accepting something." 44 Standard form contracting fails to meet these requirements when refusing to buy the product is not a meaningful option. In such cases, it is not "actually possible for one to do otherwise" than enter the contract; hence, entering it is "merely passive acquiescence in accepting something" and not "an affirmative action in doing something."

If this is correct, enforcing standard form contracts flies in the face of the following fundamental principle of democratic political organization: absent special circumstances, a private party does not have the power to unilaterally impose legally

\footnotetext{
${ }^{44}$ Radin, supra n. 7, at 1126.
} 
enforceable obligations on other adult parties. ${ }^{45}$ Exceptions aside, only governments can legitimately exercise such power. Normally, the only way a private party can impose legally enforceable terms on another adult party is to secure the latter party's free assent to being bound by the terms. As Mark Lemley notes, "Assent by both parties to the terms of a contract has long been the fundamental principle animating contract law. Indeed, it is the concept of assent that gives contracts legitimacy and distinguishes them from private legislation." 46

\section{B. The Solution}

The problem is an illusion. In an ideal formation process, buyers do freely assent to the terms of standard form contracts; hence, consent is free in practice to the extent practice approximates the ideal. Ironically, it is precisely the no-negotiation aspect of standard form contracting that promotes buyers' freedom.

The key point is that even a highly constrained choice can, depending on the circumstances, be an entirely free choice. Imagine, for example, that you have your heart set on a vacation in the Cayman Islands; unfortunately, your tight budget cannot afford the prohibitively expensive food in the Caymans. Your solution is to constrain your food choices by opting for an "all inclusive" vacation package which offers airfare, hotel, and food for a single relatively low price. In doing so, you voluntarily constrain your food options in order to freely realize your vacation goal. Contrast the thief example. You do have an option: You could refuse and be shot. The gun-compulsion violates your

${ }^{45}$ See Lemley, Terms of Use, supra n. 1, at 464 - 65.

${ }^{46} I d$. 
freedom of choice, not because it leaves you without any option, but because it leaves you without a meaningful one. In the Cayman islands vacation example, eating the hotelprovided-food is a meaningful option in the sense that it is an essential means to realizing your vacation goal. Similarly, the no-negotiation aspect of standard form contracts does not violate freedom because the use of the contracts does not deprive buyers of a meaningful choice.

Carol's water heater purchase illustrates the point. The demise of the water heater was an unwelcome intrusion that disrupted her pursuit of important goals; she wants to return pursuing those goals as quickly as possible by spending the minimum time and effort necessary to obtain a water heater on acceptable contractual terms. ${ }^{47}$ The standard form contract offers her a pre-packaged deal which--assuming an ideal formation process--she knows is acceptable without even having to read the contract. Entering the contract is a highly cost-effective means for her to freely pursue her goals. In this way, entering the contract enhances her freedom. Indeed, Carol meets two of Radin's three requirements for free consent.

Radin insists that free "[c]onsent requires [1] a knowing understanding of what one is doing [2] in a context in which it is actually possible for one to do otherwise, and [3] an affirmative action in doing something, rather than a merely passive acquiescence in accepting something." ${ }^{48}$ Carol meets the first and third requirements. She has "a knowing understanding of what [she] is doing" since she knows the contractual terms are acceptable. In addition, entering the contract is a cost-effective means to further the

\footnotetext{
${ }^{47}$ W. David Slawson, Standard Form Contracts and the Democratic Control of Lawmaking Power, 84 HARV. L. REV. 529, 532(1971) (emphasizing the scarcity of time in modern life).

${ }^{48}$ Radin, supra $\mathrm{n} .7$, at 1126.
} 
pursuit of important goals, so entering it is not "passive acquiescence" but an "affirmative action" that fits into an overall plan aimed at effectively realizing ends. The only requirement Carol fails to meet is that it should be "actually possible for one to do otherwise." It is not possible for Carol to do otherwise-in the sense that she has to have a water heater, and any contract under which she purchases one will almost certainly be a no-negotiation contract containing similar terms. But it is precisely the possibility of negotiation that Carol does not want. She wants the pre-packaged deal as an convenient, cost-effective way to pursue ends that are important to her. It is the need not to negotiate that enhances Carol's freedom. ${ }^{49}$ But doesn't the no-negotiation contract nonetheless deprive Carol of the freedom to negotiate if she wanted to? And, to that extent, doesn't it violate freedom? The answer is that Carol does not want to negotiate. Why would she? She knows the terms are acceptable in the sense that she regards them as the terms to which she ought to agree. Negotiation would be pointless.

\section{Conclusion}

In an ideal formation process, the use of standard form contracts results in acceptable terms and promotes freedom. As noted earlier, we, should for this reason, adopt the ideal formation process as a normative goal; we should, that is, try to ensure that practice sufficiently closely approximates that ideal. I now turn the question of the extent to which the use of EULAs approximates the ideal formation process. To what

\footnotetext{
${ }^{49}$ This conclusion is consistent with Karl Llewellyn's claim that the law should create an assumption of consent to standard terms and enforce them as long as they are not unfairly presented or unfair in their substance. See KARL LLEWELlyn, THE COMMON LAW TRADITION: DECIDING APPEALS 370 - 371 (1960). The courts generally take Llewellyn's approach. See Hillman \& Rachlinski, supra n. 1, at 455.
} 
extent, that is, does practice approximate the assumptions of norm completeness, inconsistency-detection, and a sufficiently term-competitive market?

\section{The Lack of Value-Justified Norms in EULAs}

I focus entirely on norm completeness. I do not mean to suggest that it is unproblematic to assume that the relevant markets are sufficiently term-competitive, or even that it is unproblematic to assume that the inconsistency-detection assumption is approximately true. There are two reasons for focusing on norm-completeness. The first is that the assumption fails to hold for EULAs; the second is that it illuminates the academic criticisms of EULAs to set those criticisms in the context of an analysis of the failure of the norm-completeness assumption.

Norm completeness fails because, in the case of certain key contractual provisions, relevant norms do exist, but they are not value-justified. The consequences of this failure are that the relevant terms are unacceptable and reduce freedom.

Acceptability: If you are contractually bound to act in accord with a term governed by a norm that is not value-justified, you are required to act as you think you ought not to act given your values. The term is consequently unacceptable; acceptable terms are terms governed by norms which are justified in light of our values. ${ }^{50}$

Freedom: Being bound to act in accord with an unacceptable term reduces your freedom since the seller requires you to do what you think you ought not to do. Your freedom is reduced because someone else requires you to act contrary to what you would

\footnotetext{
${ }^{50}$ See supra Section III(A)(1).
} 
have chosen to do without their interference. ${ }^{51}$ Market forces are unlikely to remedy this situation and hence legal action is required to ensure that the offending terms are replaced or modified in appropriate ways.

Before arguing that EULAs contain terms not governed by value-justified norms, one preliminary is in order. It is helpful to distinguish between two types of contractual terms: risk allocation terms, and normal course terms. The lack of value-justified norms occurs only with the latter.

\section{A. Two Types of Terms}

Risk allocation terms assign the risks associated with product malfunctions; they include warranties, limitations on liability, and arbitration clauses. Normal course terms do not assign malfunction risks; rather, they specify obligations arising in the normal course of the product's performance (e. g., an obligation to have the products serviced only by authorized service personnel). ${ }^{52}$ Any contractual provision imposing an obligation is either a risk allocation term or a normal course term. There are, after all, only two possibilities: either the contract is performed as promised, or it is not. Terms relevant in the first eventuality are normal course terms; terms relevant in the second are risk allocation terms.

\footnotetext{
${ }^{51}$ See e. g., RICHARD WARNER, FREEDOM, ENJOYMENT, AND HAPPINESS, Chapter III (1987) (explaining and defending freedom as self-direction in light of one's values).

${ }^{52}$ The purchaser of a new car, for example, is typically obligated to have the car serviced by authorized mechanics on pain of invalidating warranties provide by the seller. The obligation to make periodic payments is another example of a normal course obligation.
} 
Normal course terms are relatively rare in standard form contracts governing the sale of non-digital consumer goods. ${ }^{53}$ When you buy a hair dryer, for example, the seller typically does not impose significant contractual restrictions on your use of the hair dryer. You simply become the owner of that piece of personal property and may, within broad limits, do with it as you wish. In EULAs, on the other hand, sellers typically retain ownership to the software and merely license certain uses of it. ${ }^{54}$ Normal course terms define the limits of the license. The norms governing certain crucial limit-defining terms turn out not to be value-justified.

\section{B. Risk Allocation Terms}

Completeness and clarity call for a brief consideration of risk allocation terms.

Courts have refused to enforce at least three types of risk allocation terms in EULAs: restrictions on class actions, ${ }^{55}$ unreasonable arbitration clauses, ${ }^{56}$ and unreasonable choice of law and choice of forum provisions. ${ }^{57}$ The effect in each case was to severely circumscribe the ability of buyers to obtain effective redress against a breaching buyer. The litigation does not, however, suggest a lack of value-justified norms, just the opposite. There is a value-justified norm violated by including such terms in a standard

\footnotetext{
${ }^{53}$ See supra n. 52 for examples of normal course terms that do appear in contracts for the sale of non-digital products.

${ }^{54}$ See infra n. 70. .

${ }^{55}$ See Discover Bank v. Superior Court, 36 Cal.4th 148, 162-163 (2005), and Gatton v. T-Mobile USA, Inc., 152 Cal. App. 4th 571 (Cal. App. 1 Dist. 2007).

${ }^{56}$ See Comb v. PayPal, Inc., 218 F. Supp. 2d 1165, 1177 (N. D. Cal. 2002).

${ }^{57}$ See Aral v. Earthlink, Inc., 36 Cal. Rptr. 3d 229, 231 (Cal. App. 2d 2005).
} 
form contract: terms in a standard form contract should not deprive buyers of the practical possibility of a judicial remedy. The cases reveal courts refusing to enforce contractual terms when overreaching sellers violate this norm.

In general, risk allocation terms in EULAs have generated relatively little controversy. One plausible explanation is that software, after all, is still a product, and that the risk allocation issues which arise in regard to software are not all that different from the risk allocation issues arising in regard to non-digital products. It is, therefore, reasonable to assume that the norms relevant in non-digital standard form contracts have proven readily adaptable to the software context. It would be interesting to pursue this line of inquiry, but I will not do so here; instead, I turn to normal course terms.

\section{Normal Course Terms}

EULAs contain significant normal course terms which fail to be governed by value-justified norms. In support of this claim, I consider two normal course terms, terms which have been at the center of the debate about EULAs: prohibitions on reverse engineering; and, prohibitions on the allowing transfers of the software to third parties. Both terms restrict the intellectual property rights buyers would otherwise typically acquire when purchasing the software. In each case, the terms are consistent with the relevant, prevailing norm; however-as the criticisms in the literature clearly establish-the norms are not value-justified. After discussing reverse engineering and transfers to third parties, I consider whether there are other terms in EULAs which are not governed by value-justified norms. 


\section{Reverse engineering}

Reverse engineering software consists in examining its programming in order to learn how the software works. ${ }^{58}$ Under federal copyright law, reverse engineering is permissible as a fair use provided it is done for a legitimate purpose (such as to gain access to functional specifications necessary to make a compatible program), and when reverse engineering provides the only means of access to those elements of the software that are not protected by intellectual property rights. ${ }^{59}$ Software licenses, however, typically prohibit reverse engineering. ${ }^{60}$ The main motive for doing so is to control the ability to write programs (called "applications" in this context) which interoperate with the seller's program (called a "platform"). ${ }^{61}$ Many software manufacturers believe they gain a competitive advantage by controlling interoperability. ${ }^{62}$ Contractual prohibitions on reverse engineering help provide such control. The reason lies in the fact that, to write an interoperable application, the application developer usually needs to know facts about

\footnotetext{
${ }^{58}$ ELDAD EILAM, REVERSING: SECRETS OF REVERSE ENGINEERING viii (2005).

${ }^{59}$ Sega Enters. Ltd. v. Accolade, Inc. 977 F 2d 1510, $1523-24\left(9^{\text {th }}\right.$ Cir. 1993).

${ }^{60}$ See Pamela Samuelson \& Suzanne Scotchmer, The Law and Economics of Reverse Engineering, 111 YALE L. J. 1575, 1661 (2002) [hereinafter, Samuelson \& Scotchmer, Reverse Engineering].

${ }^{61}$ Sellers are not primarily concerned to prevent the development of competing products. Reverse engineering software is difficult and expensive to be an efficient way to develop a competing product. Samuelson \& Scotchmer, Reverse Engineering, supra n. 60, at 1613 - 1615.

${ }^{62}$ As Samuelson and Scotchmer note, "no one would dispute that Microsoft's control over the APIs for developing applications for the Windows platform is an important source of its enduring power in this market." Samuelson \& Scotchmer, Reverse Engineering, supra n. 60, at 1620. To write a program that will run on Microsoft Windows, you need to know the application program interfaces (APIs). Microsoft maintains the APIs as a trade secret and licenses access to them. Programmers unwilling to enter into the necessary license agreement have one other way of gaining access to the APIs: reverse engineer Windows. Microsoft contractually blocks this path to access by prohibiting reverse engineering in the Windows license.
} 
the platform maintained as trade secrets. The developer typically has two ways to obtain the requisite knowledge: reverse engineer the software, or enter into a license agreement with the platform sellers. Contractually prohibiting reverse engineering increases a platform seller's control over the creation of interoperable products by compelling (law abiding) application developers to negotiate with them to obtain the knowledge they need.

The current norm is that platform sellers may contractually prohibit reverse engineering. A norm is a sanction-supported regularity which exists in part because people think they ought to act in accord with the regularity. There is a relevant sanctionsupported regularity: application developers (for the most part) abide by sellers' contractually imposed restrictions on reverse engineering, restrictions the courts enforce. For this regularity to qualify as a norm, application developers must abide by the restrictions because they think they ought to. It may appear that people do not think they ought to conform. Commentators argue that sellers should not be allowed to impose prohibitions on reverse engineering, ${ }^{63}$ and there are situations in which buyers would prefer to reverse engineer instead of negotiate a license agreement. ${ }^{64}$ So why believe buyers think they ought to abide by contractual prohibitions on reverse engineering? Because the restrictions are (currently) legally enforceable, and the buyers think that they ought to abide by the law. ${ }^{65}$

\footnotetext{
${ }^{63}$ See infra text accompanying notes $66-68$.

${ }^{64}$ See Samuelson \& Scotchmer, Reverse Engineering, supra n. 60, 1615 - 20.

${ }^{65}$ See Section I(A)(1).
} 
The crucial question is whether the norm is value-justified. A norm is valuejustified if we would, after sufficient, adequately informed, and unbiased reflection, regard conformity to the norm as justified in light of the values we hold. It is extremely unlikely that we would so conclude. Those who have carefully considered the question conclude — tentatively or unequivocally — that sellers should not have unlimited discretion to prohibit reverse engineering. The fundamental reason is that allowing reverse engineering is an important factor in promoting innovation and competition, and in ensuring compatibility between products. As Samuelson and Scotchmer note in their definitive analysis of reverse engineering,

... the welfare effects of reverse engineering in the software industry are ... complex ... However, on balance, reverse engineering and interoperability are important because they promote development of a wider range of software from a wider array of developers than a market in which platform developers were insulated from reverse engineering. To the extent that the enforcement of antireverse engineering clauses would have a detrimental effect on competitive development and innovation, legal decisionmakers may be justified in not enforcing them. ${ }^{66}$

Julie Cohen and Mark Lemley reach a less tentative conclusion than Samuelson and Scotchmer's "legal decisionmakers may be justified in not enforcing" prohibitions on reverse engineering. Cohen and Lemley note that " $[\mathrm{t}]$ he wisdom of permitting reverse engineering of software has been extensively debated in the last two decades, ${ }^{\circ 7}$ and they conclude that "advocates of reverse engineering have the better part of the argument.",68

\footnotetext{
${ }^{66}$ Samuelson \& Scotchmer, Reverse Engineering, supra n. 60, at 1629 - 30.

${ }^{67}$ Julie E. Cohen \& Mark A. Lemley, Patent Scope and Innovation in the Software Industry, 89 CALIFORNIA L. REV. 1, 21 (2001).

${ }^{68} I d$.
} 
I conclude that the current norm, "Allow sellers to prohibit reverse engineering" is not value-justified. It follows that including prohibitions on reverse engineering in standard form contracts used to mass market software imposes on buyers unacceptable terms which violate freedom. Enforcing such terms is, therefore, inconsistent with realizing the normative goal of approximating the ideal formation process; hence, courts should not enforce them, and, if courts continue to do so, legislative action should ensure that such terms are not enforceable. But is legal intervention clearly necessary? Why won't the market remedy the situation? It could do so by leading to the emergence of a value-justified norm governing restrictions on reverse engineering; once such a norm emerged, sellers would offer terms consistent with the norm (assuming a sufficiently close approximation to the ideal formation process). This has not yet happened, and the persistence in EULAs of prohibitions on reverse engineering provides reason to think that the future will resemble the past.

It bears emphasis that this conclusion holds only for the standard form contracts used to mass market software. It does not follow for contracts where parties of roughly equal bargaining power explicitly negotiate terms. In the standard form case, buyers (in an ideal formation process) rely on the existence of value-justified norms to ensure that the terms are acceptable. There is no such reliance in the case of explicitly negotiated terms. Of course, one may argue that prohibitions on reverse engineering should not be enforceable in such cases as well; my point is only that this conclusion does not follow from the arguments given here.

What are the prospects for repairing this defect in EULAs? The problem is that norm completeness fails because the current norm governing contractual restrictions on 
reverse engineering is not value-justified. The solution is to ensure that a relevant valuejustified norm exists in regard to such restrictions. It does not seem difficult to propose such a norm; indeed, Julie Cohen and Mark Lemley argue persuasively that the norm should be that sellers may not prohibit reverse engineering when it is done for a legitimate purpose (such as to gain access to functional specifications necessary to make a compatible program), and when reverse engineering provides the only means of access to those elements of the software that are not protected by intellectual property rights. ${ }^{69}$

\section{Prohibitions on transfers to third-parties}

In the typical EULA, the seller retains title to the software, licensing certain uses, but prohibiting or limiting the transfer of the software to third parties. ${ }^{70}$ If sellers did not retain title, buyers could resell the software under the Copyright Act's "first sale" doctrine, which provides "the owner of a particular copy ... is entitled . . to sell or otherwise dispose of the possession of that copy." "71 Digital copies do not degrade in the way non-digital copies do, and sellers fear that the widespread availability of "good as new" used software will have a serious impact on the market for new software. ${ }^{72}$ The

${ }^{69} I d$. at 6 (2000) (proposing "a limited right to reverse engineer patented computer programs to permit the study of those programs and the duplication of their unprotected elements").

${ }^{70}$ See R. Anthony Reese, The First Sale Doctrine in the Era of Digital Networks, 44 BosTON COLLEGE L. REV 577, 614 (2003) (noting that EULAs "often" license only certain uses and do not transfer title). See, also, Lydia Pallas Loren, Slaying the Leather-Winged Demons in the Night: Reforming Copyright Owner Contracting with Clickwrap Misuse, 20 OHIO N. U. L. REV. 495, 498 - 99 (2004) ("Many contracts used by copyright owners today seek to . . . limit the application of the first sale doctrine

${ }^{71} 17$ U.S.C. \$109(a)).

${ }^{72}$ Pamela Samuelson, Digital Media and The Changing Face of Intellectual Property Law, 16 RUTGERS COMPUTER \& TECH. L.J. 323, 325 - 8 (1990). 
used software would be considerably less expensive (or available for free from libraries), yet might nonetheless meet the needs of many buyers.

The current norm is-roughly--that sellers may contractually prohibit transfers to third parties. This is a sanction-supported regularity: EULAs do routinely prohibit transfers, and courts enforce the prohibitions. ${ }^{73}$ But do people think that they ought to abide by the regularity? They must if the regularity is to qualify as a norm, and it may seem they do not. After all, people routinely allow friends and acquaintances to copy their software ${ }^{74}$ licensed users of Macromedia's Dreamweaver, for example, may lend the installation $\mathrm{CD}$ to friends for them to install the program (although doing so is prohibited by the license). This does not, however, show that people routinely transfer their own copies to others; it does not show that licensed users of software routinely sell or give away their own copies of the program. To some extent, they very well may; however, two facts are clear: there is no well-established secondary market in used software; and, libraries do not routinely loan a wide range of commercially available software (you cannot borrow a copy of Windows, for example). It is certainly plausible that at least part of the explanation is that people think they ought not to make the software available in these ways. The "ought" here may be purely prudential. They may think that the activity is illegal and that they are very likely to get sued by the manufacturer, and on that basis they think they ought not to sell. For the sake of argument, let us agree that the current norm is that sellers may, at least, contractually

\footnotetext{
${ }^{73} I d$.

${ }^{74} I d$. (pointing out that users routinely ignore the restriction).
} 
prohibit the systematic, public transfer of software via a secondary market or via libraries.

Even if this is the norm, it is not value-justified. The argument is essentially the same as in the case of reverse engineering: Those who have carefully considered the question conclude that sellers should not have the largely unlimited ability to prohibit or restrict lending or reselling of software. The argument emphasizes the value we place on communication and the dissemination of knowledge and contends there is an unacceptable conflict with this value when sellers prohibit the commercial transfer of software in a secondary, used-software market, and the non-commercial transfer of software by public and private archives and libraries. ${ }^{75}$ A library which has, for example, acquired the web site creation program, Dreamweaver, under a EULA which prohibits allowing a third party to copy the software, cannot legally allow me to install—even temporarily - the program on my computer so that I can create a web site. ${ }^{76}$ The EULA restriction prevents me from communicating and disseminating knowledge over the web.

${ }^{75}$ See Reese, supra n. 70, at 646 - 648 (2003) (noting the negative impact on libraries and on the availability of software generally), and Lydia Pallas Loren, Slaying the Leather-Winged Demons in the Night: Reforming Copyright Owner Contracting with Clickwrap Misuse, 20 OHIO N. U. L. REV. 495, 496 (2004) (arguing sellers restrict transfers to third parties to "obtain advantages that may not be socially beneficial).

${ }^{76}$ The Internet has greatly expanded possibilities for libraries and archives. See Rebecca Tushnet, My Library: Copyright and the role of Institutions in a Peer-To-Peer World, 53 UCLA L. REV. 977 (2006) (discussing the development and importance of public and private archives on the Internet). Rebecca Bolin nicely summarizes the value libraries as a mechanism for the noncommercial transfer of works:

In the Nineteenth Century, American libraries were founded to be public places of education and betterment, as democratic institutions. The library was a place of education that allowed the democratic governing populace to be sufficiently informed. As an economic matter, the library was the answer to the tension between market-based information production and intellectual property as a necessary public good. Libraries are an exception to allow a limited monopoly on copyrighted works.

Rebecca Bolin, Locking Down the Library: How Copyright, Contract, and Cybertrespass Block Internet Archiving, 29 HASTINGS COMM. \& ENT. L. J. 1, 10 (2006) 
It does, that is, to the extent that I am unable to acquire a web site creation program by other means. If there were a secondary market in—relatively cheap—used software, I might be able to buy a copy. However, the restriction on transfers to third-parties prevents the formation of such a market and thereby prevents the acquisition of software by those of limited financial means.

We should not, therefore, regard the "sellers may restrict transfers to thirdparties" norm as value-justified, and, as with prohibitions on reverse engineering, it follows that, standard form contracts used to mass market software, such terms should not be enforced. The argument is the same as before: enforcing such terms is inconsistent with realizing the normative goal of approximating the ideal formation process, and the persistence in EULAs of restrictions on transfers to third-parties is evidence that market forces are inadequate to eliminate such terms. As in the case of prohibitions on reverse engineering, this conclusion follows only for the standard form contracts used to mass market software and not for contracts where parties of roughly equal bargaining power explicitly negotiate terms. The difference is that, in standard form contracting, buyers rely on the existence of value-justified norms to ensure that the terms are acceptable while there is no such reliance in the case of explicitly negotiated terms.

What are the prospects of remedying this failure of the norm completeness assumption by ensuring that an appropriate, value-justified norm governs restrictions on transfers to third-parties? Should sellers have some ability to restrict transfers to thirdparties? The answer is unclear. As Anthony Reese notes, "[t]he first sale doctrine has been a major bulwark in providing public access by facilitating the existence of used book and record stores, video rental stores, and, perhaps most significantly, public 
libraries."77 However, as Reese emphasizes, “[t]echnology has begun to change dramatically the environment in which the first sale doctrine operates," persuasively that, given the technological and economic complexity of the situation, it is too soon to tell what sort of restrictions on the first sale doctrine, if any, are appropriate. ${ }^{79}$ There is, however, no evident reason to think that will not eventually be able to identify an appropriate norm governing restrictions on transfers to third-parties.

\section{Same Problem, Other Terms?}

Are there other terms in EULAs which are not governed by value-justified norms? A complete treatment of EULAs would catalogue their typical terms and determine whether they were governed by relevant, value-justified norms. Here, I will confine myself to suggesting two more terms which may raise concerns about lack of valuejustification. First: EULAs typically impose restrictions on publishing the results of benchmark tests. Benchmark tests of software may report misleadingly poor performance if the tested software is improperly installed, or if it is not the most recently updated version. Sellers typically protect their interest in accuracy by imposing conditions in the EULA on the publication of benchmark tests. ${ }^{80}$ Such restrictions

\footnotetext{
${ }^{77}$ Reese, supra n. 70 , at 577.

${ }^{78} I d$. at 578 .

${ }^{79} I d$. at $616-652$.

${ }^{80}$ Prior to 2001, for example, Network Associates sold its popular McAfee anti-virus program, VirusScan, subject to a clickwrap agreement which contained the following provision: "The customer shall not disclose the result of any benchmark test to any third party without Network Associates' prior written approval." See People v. Network Associates, Inc. 758 N.Y.S.2d 466, 457 (2003).
} 
conflict with the value we place on free speech, and hence raise questions about whether a norm permitting such restrictions is value-justified. ${ }^{81}$ Second: EULAs often grant sellers the right to electronically access the hard drive in order to verify that the use of the software complies with the requirements of the license. ${ }^{82}$ Would a norm permitting such access be value-justified? Brick-and-mortar analogies suggest otherwise; Gucci does not have the right to enter my home or stop me on the street to determine whether the items I have bearing the Gucci label are really Gucci.

\section{Conclusion}

Currently, relevant norms permit sellers to prohibit reverse engineering and restrict transfers to third-parties. These norms are not value-justified; hence, terms prohibiting reverse engineering and restricting transfers to third-parties are unacceptable and violate freedom. The terms should, therefore, not be enforced. The remedy for this defect in EULAs is to identify, or create, appropriate, value-justified norms. There is no evident reason why we should not be able to do so.

EULAs are legitimately seen as a form of Internet contracting when the software is purchased over the Internet and delivered by downloading it; indeed, Internet purchase

\footnotetext{
${ }^{81}$ There is a norm, familiar from but certainly not confined to free speech jurisprudence: a restriction on speech is not justified if there is a less restrictive alternative that adequately serves the purpose of the original restriction. "Explicit approval" provisions arguably conflict with this norm as there appears to be a less restrictive alternative: allow disclosure of results without requiring seller approval as long as the test complies with specified conditions (posted on a web site, for example). Benchmark testing restrictions now tend to be of the "comply with conditions" type. Such conditions began to replace "explicit approval" conditions after the court struck down Network Associates' "explicit approval" condition in People v. Network Associates, supra n. 80, at 468 .

${ }^{82}$ For example, the license agreement for Windows Vista operating system contains such provisions. See Michael Geist, Vista's Fine Print, http://www.michaelgeist.ca/content/1641/135.
} 
and delivery is arguably an ideal way to secure a buyer's agreement to a standard form, no-negotiation contract: the installation program is already on the buyer's hard drive before he or she can read the contract. However, the challenges EULAs raise- the concerns about reverse engineering and transfers to third parties-would arise even if the Internet were not involved. The same is not true of TOUs. Not only are TOUs formed over the Internet, they also govern our use of web sites; as a result, TOUs raise contractual issues that would not arise in the absence of the Internet.

\section{TOUs}

A complete treatment of TOUs would catalogue the types of risk allocation and normal course terms they contain and would determine whether the terms are governed relevant, value-justified norms. I will not offer such a treatment. I focus instead on the fact that TOUs typically contain provisions permitting the web site to collect and use information about web site visitors. I advance three claims. The first is that the current norm is that a business may collect and use a wide range of information about consumers. The second is that this norm is not value-justified; the third, that it is unlikely that this lack of value-justification will be remedied any time soon.

In the United States, a business may, with relatively few restrictions, impose contractual terms that allow them to collect and use wide variety of different types of information about consumers. ${ }^{83}$ I contend that this is not only the law, but also the prevailing norm, at least in the case of online businesses. The first part of the definition of a norm is fulfilled for online businesses: contractually-mediated online business

${ }^{83}$ See, e. g., Joel R. Reidenberg, Privacy Wrongs in Search of Remedies, 54 HASTINGS L.J. 877 (2003) (analyzing and criticizing the current state of privacy law). 
collection and use of information is a sanction-supported regularity. It is clearly are regularity. Online businesses routinely include in their TOUs terms allowing them to collect and use a wide variety of information about their web site visitors. Indeed, as a recent Privacy International report notes,

We are witnessing an increased 'race to the bottom' in corporate surveillance of customers. Some companies are leading the charge through abusive and invasive profiling of their customers' data. This trend is seen by even the most privacy friendly companies as creating competitive disadvantage to those who do not follow that trend, and in some cases to find new and more innovative ways to become even more surveillance-intensive. ${ }^{84}$

To remain competitive, companies increase their customer surveillance in response to increases by competitors; as a result TOUs contain terms allowing online businesses ever more expansive powers to collect and use information. This regularity is a sanctionsupported one. The courts routinely enforce contractual provisions allowing businesses to collect information. ${ }^{85}$

It may seem, however, that the second part of the definition of a norm cannot possibly be fulfilled; it may seem that consumers do not think they ought to abide by the regularity. After all, there has been, and continues to be, intense, widespread criticism of allowing business the largely unrestricted ability to collect and use information. Allowing them to do so increases the risk of harm to individuals; ${ }^{86}$ subjects us to

\footnotetext{
${ }^{84}$ Privacy International, A Race to the Bottom - Privacy Ranking of Internet Service Companies, http://www.privacyinternational.org/article.shtml?cmd\%5B347\%5D=x-347-553961.

85

86 See, e. g., Daniel J. Solove, A Taxonomy of Privacy, U. OF PA. L. REV. 477 (2006) [hereinafter, Solove].
} 
information overload; ${ }^{87}$ gives excessive, easily abused power to credit agencies, insurance companies, and businesses generally; ${ }^{88}$ has a chilling effect on decisionmaking; inhibits the development of the self $;{ }^{89}$ creates the possibility of approaching a perfect enforcement of rules and laws that would create a merciless "Big Brother" inconsistent with the true demands of justice and forgiveness; ${ }^{90}$ and puts civil society itself at risk. ${ }^{91}$ It would, however, be a mistake to conclude that consumers do not think that they ought to abide by the norm. It is still possible, and indeed likely, that they do. The reason is the simple, and by now familiar one, that the contractual provisions are enforceable, and people generally think they ought to obey the law; consequently, they ought to abide by laws that allow businesses to collect and use information. In any case, grant for the sake of argument that the current norm is that a business may impose contractual terms that allow it to collect and use a very wide range of information about consumers.

\footnotetext{
${ }^{87}$ See DiCK EASTMAN, Fighting INFORMATION OVERLOAD ON THE WEB, http://www.lulu.com/content/889152.

${ }^{88}$ See JAMes B. RULe, PrIVACY IN PERIL 32, 93 - 142 (2007) [hereinafter, RULe].

${ }^{89} I d$. at $186-188$.

${ }^{90}$ See LAWRENCE FRIEDMAN, GUARDING LIFE's DARK SECRETS: LEGAL AND SOCIAL CONTROLS OVER REPUTATION, PROPRIETY, AND PRIVACY 267 - 268 (2007); and, RULE, supra $\mathrm{n}$. 80 , at $5-6$.

${ }^{91}$ The point is made forcefully (but without use of the expression "civil society") by Robert Post, Social Foundations of Privacy: Community and the Self in the Common Law Tort, 77 CAL. L. REV. 957 (1989). See also Helen Nissenbaum, Technology, Values, and the Justice System: Privacy as Contextual Integrity, 79 WASH. L. REV. 119, 148 - 152 (2004) (emphasizing the connections between privacy, autonomy, and democracy); Julie E. Cohen, Examined Lives: Informational Privacy and the Subject As Object, 52 STAN. L. REV. 1373 (2000) (noting that threats to privacy constitute threats to "civil society"); and, Paul M. Schwartz, Privacy and Democracy in Cyberspace, 52 VAND. L. REV. 1609 (1999) (same).
} 
The essential point is that the norm is not value-justified. That is what the widespread, intense criticism of the norm shows. The many who have carefully considered the question conclude that the largely unrestricted collection and use of information by businesses is not justified in light of our values. It follows that the legal system should refuse to enforce such terms. Enforcing them is inconsistent with realizing the normative goal of approximating the ideal formation process, ${ }^{92}$ and the persistence of such terms in TOUs is evidence that market forces are unlikely to remedy the situation without legal intervention. As in the case of prohibitions on reverse engineering, this conclusion follows only for the standard form contracts used to mass market software and not for contracts where parties of roughly equal bargaining power explicitly negotiate terms.

Will this situation to be remedied relatively soon by the emergence of relevant value-justified norms? That is unlikely. Any such norms would have to strike a proper balance between two conflicting interests. One is our interest in informational privacy, in controlling what others know about us and what they do with that information; the other is efficiency. The information increases businesses efficiency, ${ }^{93}$ and, efficiency matters: the more efficient we are the less time, effort, and money we spend to achieve our desired results, and the more we have left over for other purposes. In the new technological and economic setting of the twenty-first century, we do not know how to make this tradeoff in an acceptable way. As Daniel Solove notes,

\footnotetext{
92 As with EULA restrictions on reverse engineering and transfers to third parties, this conclusion follows only for standard form, no negotiation agreements where web site visitors are relying on the existence of value-justified norms to ensure the acceptability of contractual terms.

${ }^{93}$ RULE, supra n. 88, at 156 - 162; see also Richard Warner, Surveillance and the Self: Privacy, Identity, and Technology, 54 DE PAUL L. REV. 847, 849 - 52 (2005).
} 
[p]rivacy is a concept in disarray. Nobody can articulate what it means. As one commentator has observed, privacy suffers from "an embarrassment of meanings." Privacy is far too vague a concept to guide adjudication and lawmaking, as abstract incantations of the importance of "privacy" do not fare

well when pitted against more concretely stated countervailing interests. ${ }^{94}$

I am not suggesting that we cannot find an adequate resolution to the tradeoff between our interest in privacy and the gains of efficiency. I am just suggesting it will be a long and difficult task, and, until that task is completed, we will lack relevant, value-justified norms governing contractual provisions allowing businesses to collect information about their customers' activities.

\section{Conclusion}

The requirement of value-justified norms is a powerful constraint on the enforceability of terms in standard form contracts. It makes the focus of enforceability the values of consumers since it requires enforceable terms to be consistent with norms that consumers do, or would on adequate reflection, regard as justified in light of their values. The justification for this requirement is that, by imposing it, we ensure that standard form contracting yields acceptable terms that enhance the freedom of buyers. EULAs and TOUs illustrate the point. Both contain terms which fail to be governed by value-justified norms and the failure provides a reason for refusing to enforce those terms. The ultimate remedy, however, is to identify, or create, an appropriate valuejustified norm. How are appropriate value-justified norms to be identified or, where necessary, created? The analysis I have provided raises but does not answer this question.

${ }^{94}$ Solove, supra n. 86 , at $477-8$. 